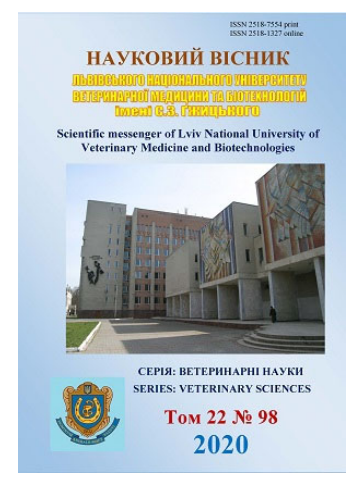

\author{
Науковий вісник Дьвівського національного університету \\ ветеринарної медицини та біотехнологій імені С.3. Гжицького. \\ Серія: Ветеринарні науки \\ Scientific Messenger of Lviv National University \\ of Veterinary Medicine and Biotechnologies. \\ Series: Veterinary sciences
}

UDC 619:616.591.44:616.217:636.92

\title{
Histogical structure of the thyroid gland in rabbits with different types of autonomous tonus
}

M. V. Zakrevska, A. M. Tybinka

Stepan Gzhytskyi National University of Veterinary Medicine and Biotechnologies Lviv, Ukraine

Article info

Received 21.04.2020

Received in revised form 26.05.2020

Accepted 27.05.2020

Stepan Gzhytskyi National University of Veterinary Medicine and Biotechnologies, Pekarska Str., 50, Lviv, 79010, Ukraine. Tel.: +38-067-454-75-10 E-mail:martazakrevska@gmail.com
Zakrevska, M. V., \& Tybinka, A. M. (2020). Histogical structure of the thyroid gland in rabbits with different types of autonomous tonus. Scientific Messenger of Lviv National University of Veterinary Medicine and Biotechnologies. Series: Veterinary sciences, 22(98), 119-127. doi: $10.32718 /$ nvlvet 9821

The research was aimed at investigating the influence of the aggregated tonus of sympathetic and parasympathetic centers on the rabbit's thyroid gland morphology. For this purpose, the rabbit males (Oryctolagus cuniculus (Linnaeus, 1758)) of Blanc de Termond breed at the age of four months, passed an electrocardiographic and variation pulsometry study. According to the results, the animals were divided into three groups: rabbits with sympathicotonia (18 animals), rabbits with normotonia (5 animals) and rabbits with parasympathicotonia (3 animals). After euthanasia, the fragments of the thyroid gland were taken out, fixed in Bouin's solution and embedded in paraffin blocks. Histological sections were prepared from the paraffin blocks and later stained with hematoxylin and eosin, as well as Gabu-Diban's aldehyde fuchsin and Heidenhain's azan. Morphometric study of follicles and cells of the gland was performed using these histopreparations. Based on the obtained data, the indices of gland activity were calculated, i.e. Brown index and the follicle-colloid index. At the same time, it was established that morphofunctional parameters of the thyroid gland depend on the typological features of the autonomous tonus. This is reflected in the thickness of the capsule, the amount of adipose tissue, the size and density of the follicles' placement, the height of the thyrocytes and the ratio between the areas of their nuclei and the cytoplasm. Rabbits with parasympathicotonia account for the higher values of half (7 from 14) of the studied parameters, while their combination suggests the functional activity of the thyroid gland of the animals in this group is higher compared to the other groups of rabbits. Also, rabbits with parasympathicotonia have a larger body weight. For normotonic and sympatheticontic rabbits, the functional activity of the thyroid gland as well as the body weight is lower and approximately of the same intensity. The existence of correlation between the separate indicators was investigated, the character of which is also related to the type of the autonomous tonus.

Key words: parasympathicotonic rabbits, normotonic rabbits, sympathicotonic rabbits, thyrocytes.

\section{Гістоструктура щитоподібної залози кролів 3 різними типами автономного тонусу}

\author{
М. В. Закревська, А. М. Тибінка
}

Львіський національний університет ветеринарної медицини та біотехнологій імені С. 3. Гжицького, м. Львів, Україна

Дане дослідження спрямоване на вивчення впливу сукупного тонусу симпатичних та парасимпатичних иентрів на морфологію шиитовидної залози кролика. Для изього групі кролів-самџів (Оryctolagus cuniculus (Ліней, 1758)) породи Термонська біла, віком 4 місяиі проведено електрокардіографічне та варіаційно-пульсометричне дослідження, за даними яких тварин поділили на три групи: парасимпатики (3 тварини), нормотоніки (5 тварин) та симпатикотоніки (18 тварин). Після евтаназї у тварин відбирали фрагменти щчитоподібної залози, які фіксували у розчині Буена та заливали в парафінові блоки. 3 останніх виготовляли гістологі- 
чні зрізи, які фарбували гематоксиліном і еозином, альдегід-фуксином за Габа-Дибаном та азаном за Гейденгайном. На гістопрепаратах проводили морфометричне дослідження фолікулів залози та ї̈ клітин (тироцитів). На основі отриманих даних вираховували індекси активності залози - індекс Брауна та фолікулярно-колоїдний індекс. При иьому, встановлено, шо типологічні особливості автономного тонусу проявляються в структурі щитоподібної залози. Це відображається у товщині капсули, кількості жирової тканини, розмірах та шільності розташування фолікулів, висоті тирочитів та співвідношенні між площами їхніх ядер $і$ цитоплазми. Значення половини (7 з 14) досліджених показників є вищими в кролів-парасимпатиків, а їх поєднання дозволяє стверджувати, щзо функціональна активність щүитоподібної залози у тварини цієї групи є вищою порівняно з іншими групами кролів. Також тварини парасимпатики мають більшу масу тіла. У кролів-нормотоніків та симпатикотоніків, як функціональна активність щзитоподібної залози, так і маса тіла, є нижчою та приблизно однаковою. Між окремими показниками досліджено наявність корелячійних зв'язків, характер яких також пов'язаний з типом автономного тонусу.

Ключові слова: кролі-парасимпатики, кролі-нормотоніки, кролі-симпатикотоніки, тирочити.

\section{Introduction}

Thyroid gland belongs to the hypothalamic-pituitarythyroid system (Ortiga-Carvalho et al., 2016). In rabbits, it consists of two parts connected by a thin isthmus and located on the larynx and trachea within the range from the anterior horn of the thyroid cartilage to the $9^{\text {th }}$ tracheal cartilaginous ring (Zhedenov, 1987). The hormones the thyroid gland produces affect the growth of the organism, the development of sexual and nervous system and are also involved in the metabolism (Jost, 1954; Krassas et al., 2010; Forhead \& Fowden, 2014; Coll, 2014; Mullur et al., 2014). Therefore, the structure of the gland of animals in general and rabbits in particular, was subjected to a comprehensive study for quite a long time. The study of the gland was performed both in terms of a healthy organism (Sugiyama \& Yagizawa, 1951; Balasundaratn \& Mookkappan, 2000; Parchami et al., 2012; Onwuaso et al., 2015; Johansson et al., 2015) and pathology (Alcaraz et al., 2003; Borges et al., 2014). In addition, a number of scholars (Sugiyama, 1954; Abdelatif \& Saeed, 2009; ALMustawfi et al., 2011; Bessalova, 2012; El-Desouki et al., 2014; Gachkar et al., 2019) conducted experimental research studying the relationship between the anatomical and physiological parameters of the gland and certain functional states of the organism. Despite a large number of studies, we have not found any data that would prove the effect of different tonus of the autonomic nervous system on the morphology of the thyroid gland of rabbits. At the same time, a similar effect was established on the structure of the adrenal gland (Zakrevska \& Tybinka, 2019). Studying this issue was the aim of our research.

\section{Materials and methods}

Animals: twenty six clinically healthy rabbit-males (Oryctolagus cuniculus (Linnaeus, 1758)) of Blanc de Termond breed, four months of age. The device MK$15,2-\mathrm{TN} 20$ was used to determine the weight of animals. Euthanasia was performed by inhalation overdose of chloroform.

For all animals, an electrocardiographic study was conducted. For this purpose, a rheograph (model P4-02) with an electrocardiographic channel and a recording device (model H338-6P) was used. The velocity of the tape when recording the cardiac signal was $250 \mathrm{~mm} / \mathrm{s}$. The received electrocardiograms were processed using a method of variation pulsometry with a study of at least 100 R-R intervals (Baevskij et al., 1984). Based on the obtained data, the animals were divided into three groups:
1) sympathicotonic rabbits (ST) - 18 animals; 2) normotonic rabbits (NT) - 5 animals; 3) parasympathicotonic rabbits (PS) -3 animals. In ST rabbits, the tonus of sympathetic autonomous centers clearly dominated over that of the parasympathetic ones. In NT rabbits, the tonus of the sympathetic and parasympathetic centers is balanced. Accordingly, in the PS rabbits, the tonus of parasympathetic centers is dominant. When carrying out a statistical analysis of the research results, the group of sympathicotonic rabbits was taken as the basis for comparing the performance of the other two groups.

For histological study, fragments of the thyroid gland were taken out of each rabbit and fixed in Bouin's solution. After 24 hours, the pieces of histological material were conducted through an upward row of alcohols, each of which was kept for 24 hours and embedded in paraffin blocks afterwards. Cuts with the thickness of $7 \mu \mathrm{m}$ were prepared from the obtained blocks using the sliding microtome MC-2. They were mounted on a slide glass and dried, then stained with Mayer's hematoxylin and eosin, Heidenhain's azan (Mulisch \& Welsch, 2010) and Gabu-Diban's aldehyde fuchsin (Falin, 1961). The histological preparations were examined under a Leica DM-2500 microscope equipped with a Leica DFC450C camera. Morphometry was performed using the Aperio Image Scope software. In this case, the following indicators were determined: the follicle area, the area of follicle lumen, the epithelium height, the thyrocyte area, the thyrocyte nucleus area.

Based on these indicators, the following parameters were calculated: 1$)$ diameter of the follicle $(d=2(\sqrt{ }(S / \pi))$, where: $\mathrm{d}-$ the follicle diameter, $\mathrm{S}-$ the follicle area, $\pi$ - the mathematical constant $=3,14) ; 2$ ) number of follicles per $1000 \mu^{2}$; 3) area of the follicle epithelium (the difference between the area of the follicle and its lumen); 4) area of the thyrocyte cytoplasm (the difference between the area of the cell and its core); 5) nuclearcytoplasmic ratio or $\mathrm{NC}$ ratio (nucleus area/cytoplasm area); 6) Brown index (follicle diameter/ $2 *$ (follicle epithelium height)); 7) follicle-colloid index (epithelium area/colloid area) (Hmelnitskiy, 1998; Bessalova, 2012).

Statistical analysis of the research results as well as correlation analysis were carried out using the StatPlus2008 software. In this case, the following parameters were calculated: $\mathrm{x}$ - sample mean, SE standard error of the mean, $r$ - correlation by Pearson. Student's $t$ test was used to establish the validity of the differences between the indices of separate groups of rabbits. In the table, this validity was represented as follows: * $-\mathrm{P}<0.05 ; * *-\mathrm{P}<0.01 ; * * *-\mathrm{P}<0.001$. 
During the research, the ethical standards for animals used for experimental purposes (Strasbourg, 1986, Kyiv, 2001) were fully observed and the methodology for conducting research was approved by the Ethics Commission of the Stepan Gzhytskyi National University of Veterinary Medicine and Biotechnologies Lviv (2016).

\section{Results}

The thyroid gland we studied had a pink color with a pale brown shade and was typically located (Fig. 1). The thyroid gland capsule consists of three layers: external or serous one, medium - fatty vessels and nerves and internal or fibrous one. The inner layer (own capsule of the gland) penetrates into the thickness of the gland and forms a connective tissue frame for follicles, which is mainly constructed of collagen fibers (Fig. 2).

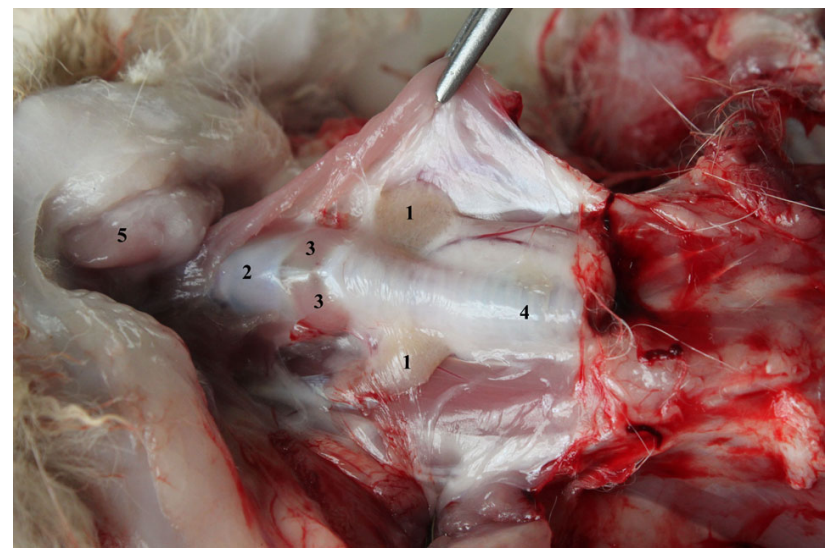

Fig 1. Topography of rabbit's thyroid gland: 1 - thyroid gland, 2 - thyroid cartilage, 3 - ring-shaped muscle, 4 - trachea, 5 - submandibular salivary gland. Gross specimen

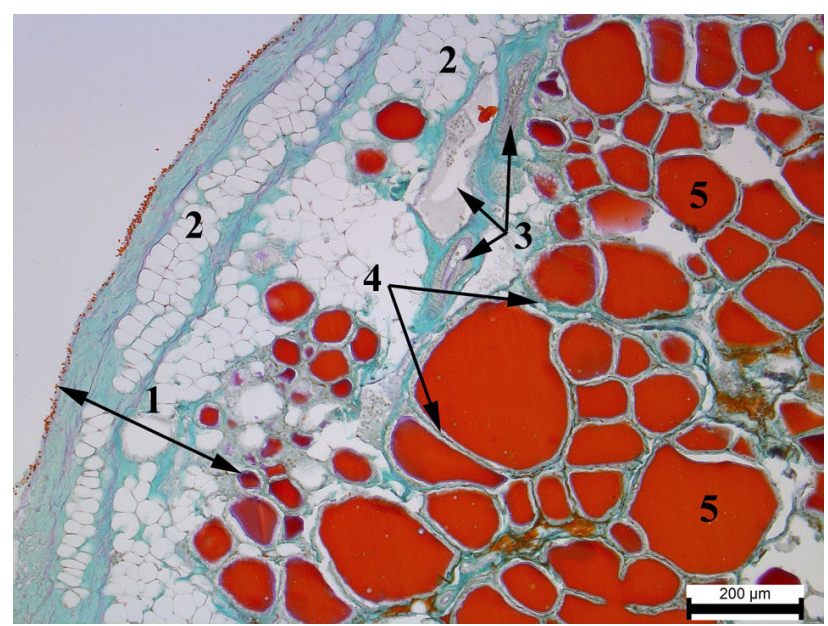

Fig 2. Fragment of the ST rabbit's thyroid gland:

1 - capsule, 2 - fat layer, 3 - vessels, 4 - connective tissue hives, 5 - lumen of the follicle with colloid.

Gabu-Diban's aldehyde fuchsin 10x10

The thickness of the capsule varies greatly even within the same gland, due to the uneven location of the fatty layer (Fig. 3, 4).

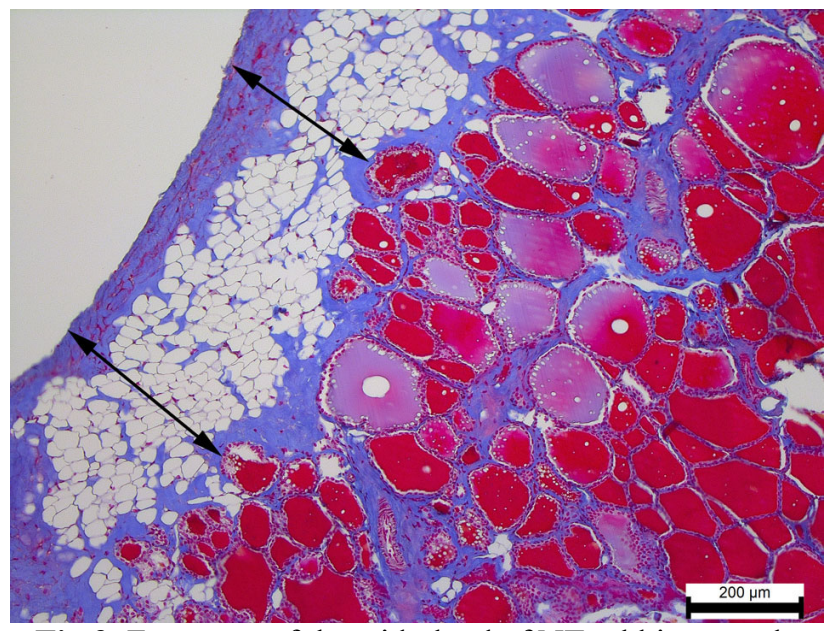

Fig 3. Fragment of thyroid gland of NT rabbit: capsule (arrows). Heidenhain's azan 10x10

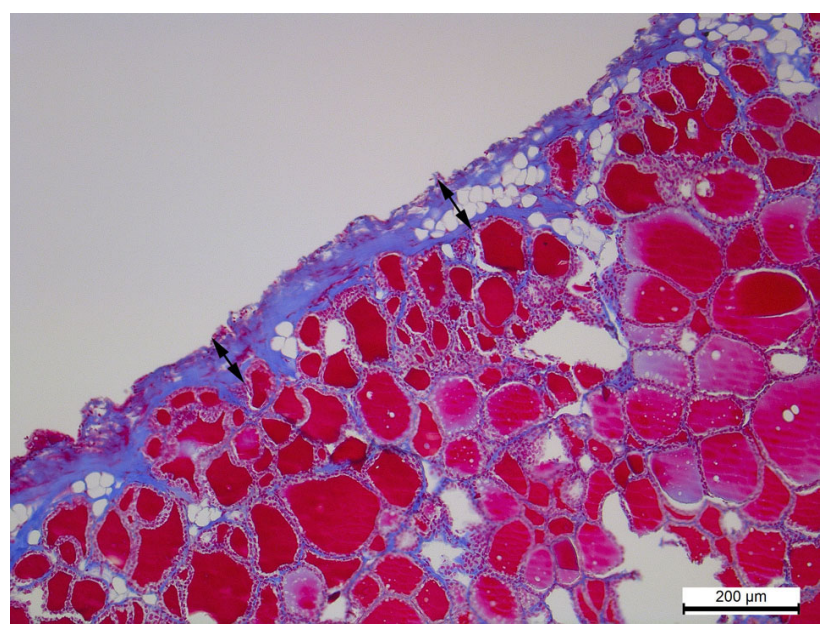

Fig 4. Fragment of thyroid gland of NT rabbit: capsule (arrows). Heidenhain's azan 10x10

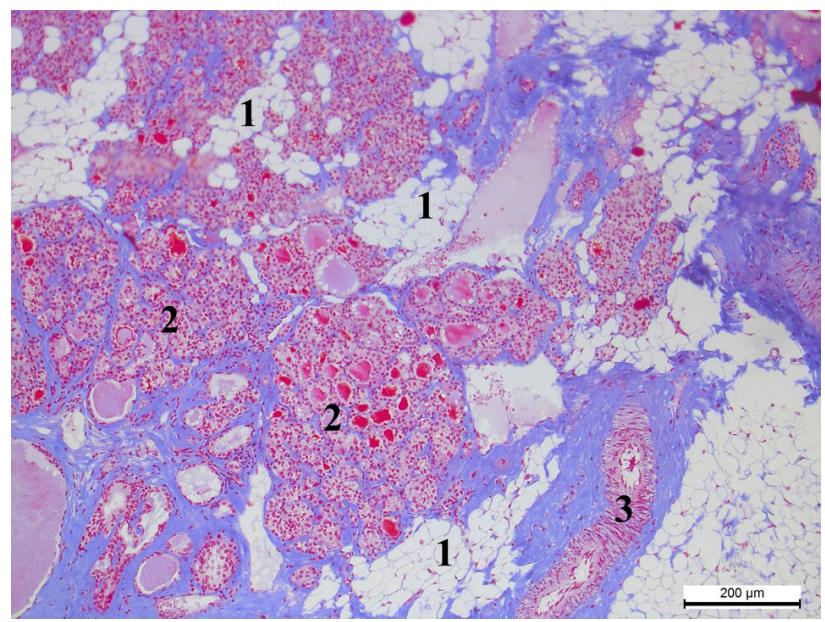

Fig 5. Fragment of the thyroid gland of PS rabbit: 1 - fatty tissue, 2 - groups of follicles, 3 - vessel. Heidenhain's azan 10x10

It is best of all expressed in PS rabbits. The indicator of thickness varies from $65.88 \mu \mathrm{m}$ to $478.6 \mu \mathrm{m}$ and the capsule itself is the thickest among the studied groups (Table 1). The thinnest capsule was found in ST rabbits $(300.05 \pm 35 \mu \mathrm{m})$. The difference between these groups 
amounts to $82.65 \mu \mathrm{m}$.

In addition to the capsule, fatty tissue is also represented in the gland parenchyma, occupying large areas and surrounding the groups of follicles (Fig. 5).

\section{Table 1}

Body weight and morphometric indices of the thyroid gland of rabbits in different groups $(x \pm S E)$

\begin{tabular}{lccc}
\hline \multicolumn{1}{c}{ Indicator } & \multicolumn{3}{c}{ Groups of animals } \\
\cline { 2 - 4 } & Sympathicotonic rabbits & Normotonic rabbits & $\begin{array}{c}\text { Parasympathicotonic } \\
\text { rabbits }\end{array}$ \\
\hline Weight of rabbit, $\mathrm{kg}$ & $3.66 \pm 0.09$ & $3.67 \pm 0.24$ & $3.92 \pm 0.43$ \\
Capsule thickness, $\mu \mathrm{m}$ & $300.05 \pm 35.00$ & $309.04 \pm 27.24$ & $382.70 \pm 68.11$ \\
Follicle area, $\mu \mathrm{m}$ & $6108.46 \pm 441.16$ & $4376.48 \pm 792.62$ & $2519.62 \pm 703.02$ \\
Follicle lumen area, $\mu \mathrm{m}^{2}$ & $4506.71 \pm 385.56$ & $2719.77 \pm 487.79$ & $1380.43 \pm 571.59$ \\
Diameter of follicle, $\mu \mathrm{m}$ & $84.37 \pm 3.10$ & $95.86 \pm 25.56$ & $54.22 \pm 7.46$ \\
Number of follicles per $1000 \mu \mathrm{m}^{2}$ & $180.14 \pm 23.50$ & $266.50 \pm 72.66$ & $260.84 \pm 76.61$ \\
Epithelium area, $\mu \mathrm{m}^{2}$ & $1601.76 \pm 78.57$ & $1656.71 \pm 310.63$ & $1139.20 \pm 138.62$ \\
Epithelium height, $\mu \mathrm{m}$ & $6.38 \pm 0.21$ & $7.54 \pm 0.65^{*}$ & $7.61 \pm 0.65^{*}$ \\
Tyrocyte area, $\mu \mathrm{m}^{2}$ & $60.40 \pm 2.43$ & $61.48 \pm 3.00$ & $89.56 \pm 12.26$ \\
Nucleus area, $\mu \mathrm{m}^{2}$ & $23.48 \pm 0.81$ & $21.68 \pm 1.40$ & $25.57 \pm 0.58$ \\
Cytoplasm area, $\mu \mathrm{m}^{2}$ & $36.69 \pm 1.76$ & $39.80 \pm 2.22$ & $64.00 \pm 12.03$ \\
Nuclear-cytoplasmic ratio & $0.70 \pm 0.02$ & $0.58 \pm 0.03^{* * *}$ & $0.47 \pm 0.11^{* * *}$ \\
Brown index & $12.85 \pm 1.04$ & $7.10 \pm 0.81^{* *}$ & $7.28 \pm 1.90$ \\
Follicle-colloid index & $0.39 \pm 0.02$ & $0.61 \pm 0.03^{* * *}$ & $1.14 \pm 0.44^{* * *}$ \\
\hline
\end{tabular}

Note: statistically reliable difference compared with the group of sympathicotonic rabbits $(*-\mathrm{P}<0.05 ; * *-\mathrm{P}<0.01 ; * * *-\mathrm{P}<0.001)$.

Follicles of the gland are of a various size and a round-oval shape mostly. However, the follicles of irregular shape systematically occur (Fig. 6). Apparent regularities of this phenomenon were not established. Nevertheless, when measuring the follicles area, significantly different results were received in experimental groups. Thus, the largest follicles were found in ST rabbits. Their area exceeds the same parameter for NT animals by $1731.98 \mu^{2}$. The area of follicles was the smallest in the group of PS rabbits. In fact, it was $3588.84 \mu \mathrm{m}^{2}$ smaller than in ST rabbits.

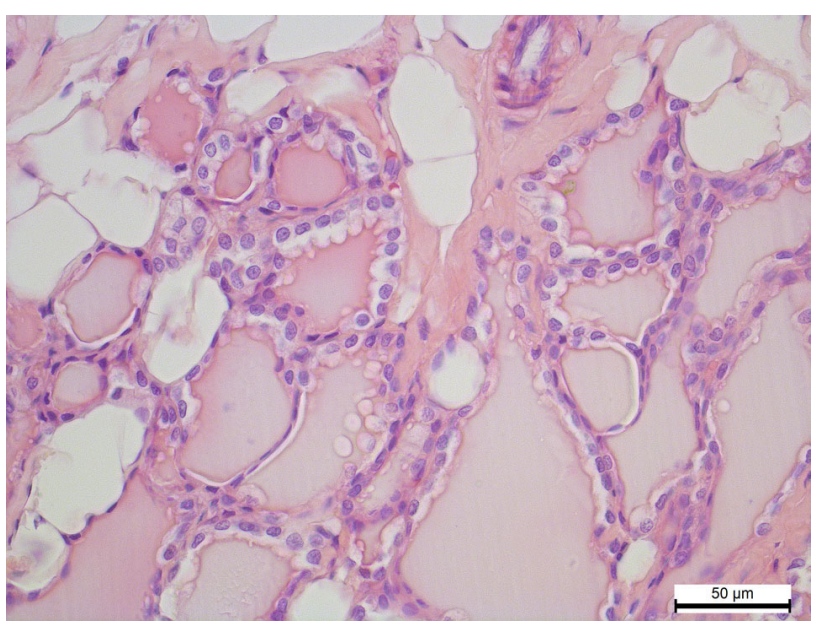

Fig 6. Follicles of different size and shape of NT rabbit. Hematoxylin and eosin 10x40

Difference between the areas of the follicle and its lumen allowed to calculate the area of the follicle epithelial layer. In NT and ST rabbits, it is almost identical and exceeds the PS group by $517.51 \mu^{2}$ and $462.56 \mu \mathrm{m}^{2}$ respectively.

An increase in the area of the epithelium occurs due to an increase in the height of its cells. Thus, in ST rabbits, the height of epithelial cells is the lowest and is $1.16 \mu \mathrm{m}$ less than in NT rabbits $(\mathrm{P}<0.05)$ and $1.23 \mu \mathrm{m}$ less than in $\mathrm{PS}$ rabbits $(\mathrm{P}<0.05)$ (Fig. 7, 8).

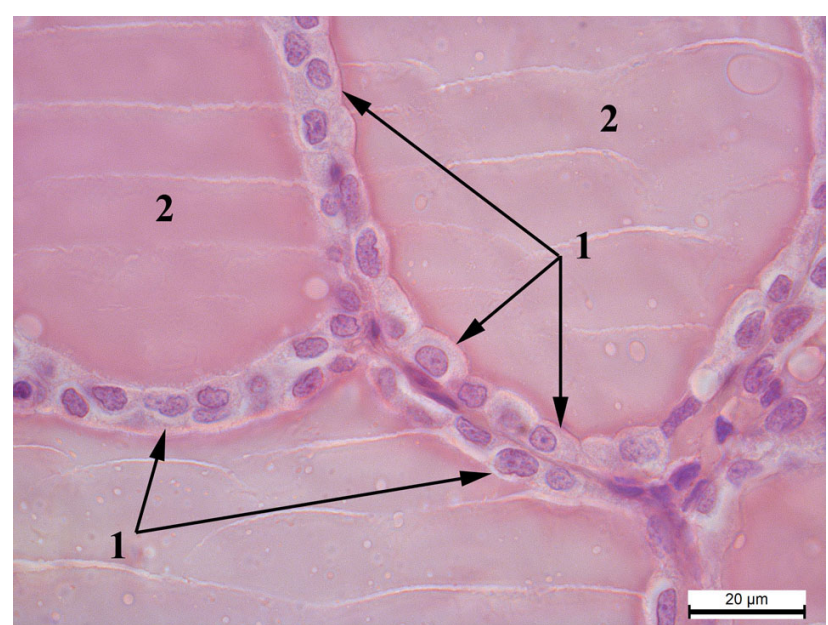

Fig 7. Follicles of ST rabbit: 1 - cells of flat form (tyrocytes), 2 - lumen of follicle with colloid. Hematoxylin and eosin 10x100

Studying the diameter of the follicles, it was found that its highest values correspond to NT rabbits and the lowest to PS rabbits. However, these figures are not reliable.

Compared to the other animal groups, the follicles of NT rabbits are distinguished not only by their larger size, but also by their denser location, which means their quantity per $1000 \mu \mathrm{m}^{2}$ of gland is the largest. This occurs due to a smaller amount of interfollicular connective tissue, in particular fat (Fig. 5, 9). In ST rabbits, this area includes 86.4 follicles less. Despite such a significant difference between the indicators, it is still not reliable, due to the uneven location of the follicles in the gland tissue, where the areas with high saturation of follicles are combined 
with the sites with significant content of stroma (Figures $9,10)$.

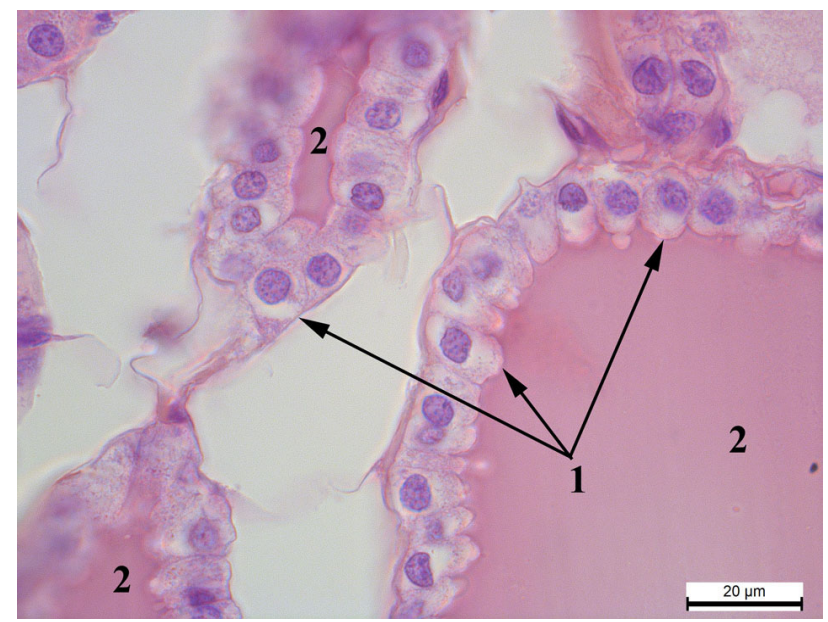

Fig 8. Follicles of NT rabbit: 1 - cells of cubic and cylindrical form (tyrocytes), 2 - lumen of follicle with colloid. Hematoxylin and eosin 10x100

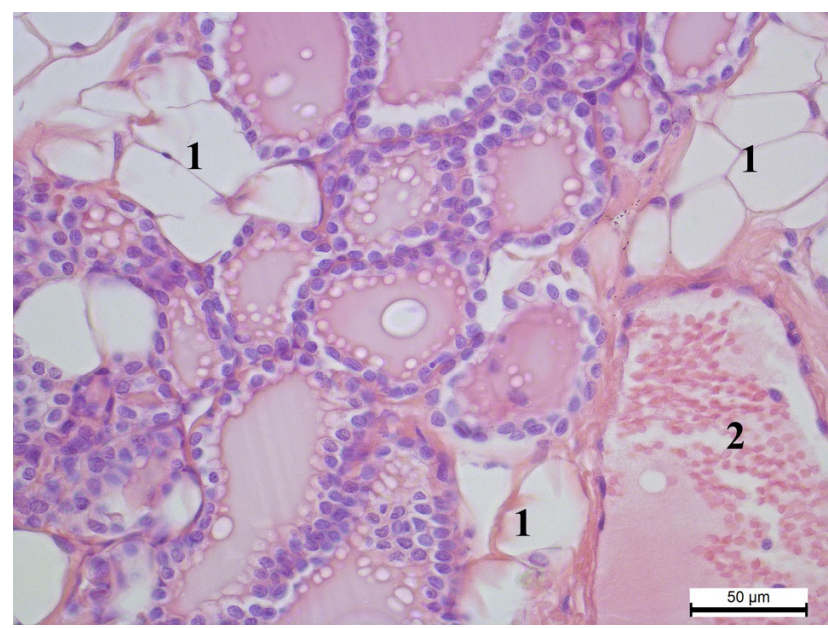

Fig 9. Density of the location of ST rabbit's follicles: 1 - adipocytes, 2 - vessel. Hematoxylin and eosin 10x40

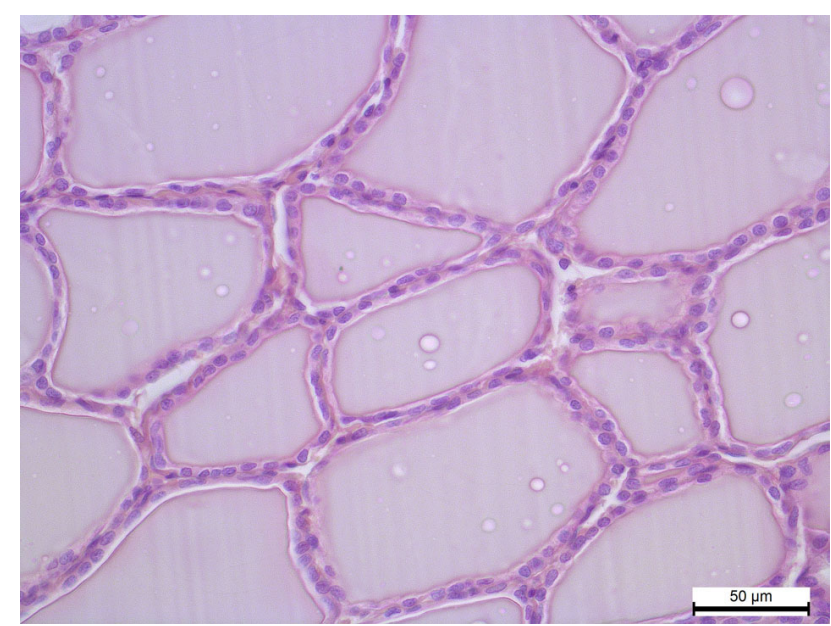

Fig 10. Density of the location of ST rabbit's follicles. Hematoxylin and eosin 10x40

The specified pattern is the most characteristic for PS and NT animals. According to this indicator, the PS rabbits also significantly dominate ST animals, namely by 80.7 follicles.

In the group of NT rabbits, a weak direct correlation $(r=0.32)$ was found between the number of follicles and the weight of rabbits. In two other groups, the correlation is inverse: for PS rabbits, $r=-0.21$, and for ST rabbits, $\mathrm{r}=-0.07$.

Between the follicles filled with colloid, clusters of tyrocytes in the form of interfollicular islets sometimes occur (Fig. 11, 12). This process is characteristic for all groups of animals. It is of no functional significance (Kachalka, 1986) and therefore its research was not carried out.

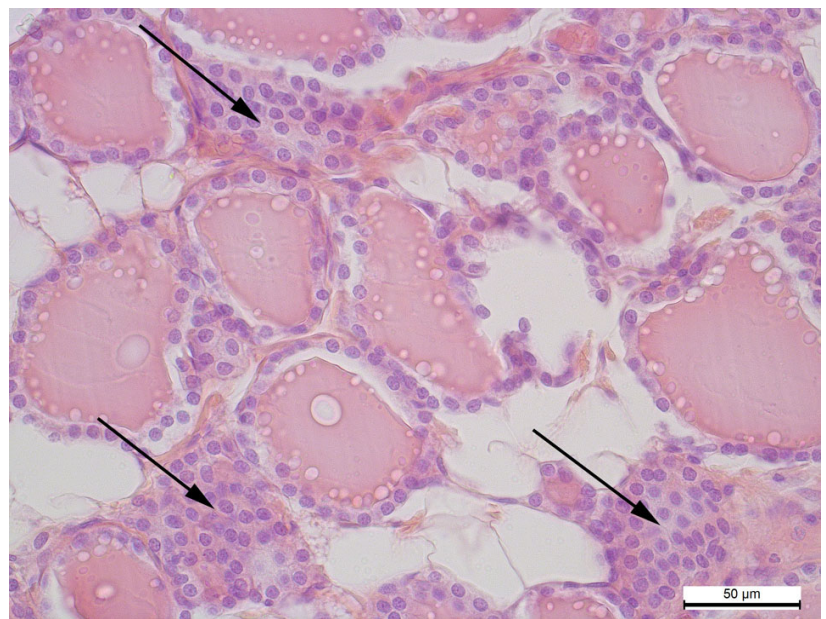

Fig 11. Accumulation of tyrocytes among the follicles of PS rabbit (arrows). Hematoxylin and eosin 10x40

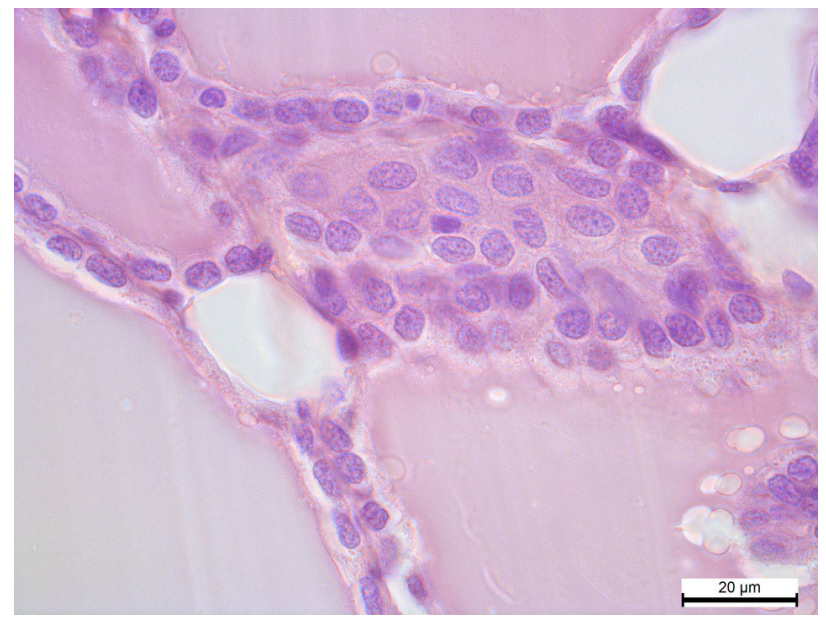

Fig 12. Accumulation of tyrocytes among the follicles of ST rabbits. Hematoxylin and eosin 10x100

Each follicle is covered with a single-layered cubic epithelium, which, depending on the functional state, can change its shape to a cylindrical or flat (Fig. 7, 8). The epithelium consists of two types of cells: tyrocytes and parafollicular C-cells (Fernández-Santos et al., 2012). In our research, only the first type of cells was studied. At the same time, the thyrocytes with the largest area were detected in PS rabbits and they exceed ST animals by $29.16 \mu \mathrm{m}^{2}$. For NT rabbits, intermediate values are observed.

Analyzing the structural parts of thyrocytes, it was 
found that PS rabbits had the highest values of both nucleus and cytoplasm area among the experimental groups of animals. In NT rabbits, the smallest nucleus area is combined with the average cytoplasm area, while in ST animals, on the contrary, the average nucleus area corresponds to the minimal cytoplasm area. However, the difference between these indicators in all groups of animals is not reliable.

The study of the morphofunctional state of cells was performed on the basis of three indices: nuclearcytoplasmic ratio (NC ratio), Brown index and folliclecolloid index.

So, the NC ratio is the largest in ST rabbits. NT rabbits occupy the second place with the ratio lower by 0,12 units $(\mathrm{P}<0.001)$. PS rabbits have the smallest NC ratio, lower by 0,23 units $(\mathrm{P}<0.001)$. These difference of $\mathrm{NC}$ ratio occurs more due to the difference in the cytoplasm area, since the area of the nuclei varies by no more than 3.89.

ST rabbits are also characterized by the highest values of the Brown index, exceeding PS rabbits by 5.57 units and NT rabbits by 5.75 units $(\mathrm{P}<0.001)$.

An entirely different type of autonomous tonus manifests itself in the values of the follicle-colloid index. Its lowest values correspond to ST rabbits. Accordingly, the NT animals dominate by 0.22 units and the PS ones by 0.75 units.

Correlation between the mentioned indices and the body weight of animals was also investigated. It was established that the weight of PS and ST rabbits had the inverse correlation with the Brown index, i.e. $r=-0.67$ and $r=-0.22$ respectively and the inverse correlation with the follicle-colloid index, i.e. $r=-0.74$ and $r=-0.22$ respectively. In NT animals, the Brown index has a strong inverse correlation with body weight $(r=-0.87)$, while the follicle-colloid index has a weak direct correlation $(\mathrm{r}=0.11)$.

At the same time, it should be noted that all the represented correlations are not reliable.

\section{Discussion}

The structure of the thyroid gland capsule of rabbits is similar to the same structure in chickens described by Balasundaratn and Mookkappan, 2000. In this case, the outer layer of the capsule is a continuation of the pretraheum plate of the cervical fascia. In both species, the majority of connective tissue fibers of the capsule is collagenous, which was also found in African reed rats (Igbokwe, 2010). The uneven location of adipose tissue in different parts of the capsule occurs partly due to its protective function and, in our opinion, is associated with the peculiarities of the gland topography with regard to the other organs (larynx, trachea, muscles and skin). To a certain extent, typological peculiarities of the autonomous tonus are reflected both in the amount of adipose tissue and in the thickness of the gland capsule.

Different size of follicles is related to their functional state. Follicles of a larger diameter are located mainly in the central part of the gland and characterized by a reduced functional activity. The periphery is more functionally filled with active follicles of the smaller size. A similar situation was also observed in mice, humans (Lee et al., 2016) and birds (Moghanlo \& Mohammadpour, 2018). The reason for such uneven location of the follicles is the development process of the gland that begins from its central part and is shown on the example of laboratory rats (Vojtkevich \& Zenzerov, 1968). The number of follicles increases until the moment of puberty due to the division of other follicles (Kachalka, 1986). At the same time, it was found that intrafollicular islets, which were also detected in our studies are not the embryos of the new follicles, but the cuttings of their tops. However, Igbokwe, 2010 describes the opposite principle of the location of follicles in the thyroid gland of wild rats, in which small follicles are located in the central part of the gland, while large and medium ones - on its periphery. Such differences may occur due to speciesspecific and environmental factors.

The irregularity of shape in some follicles may be explained by the fact that secretion in the adjacent follicles does not occur simultaneously, since they are at different stages of their functional cycle. Another reason for this phenomenon is probably the division of thyrocytes, resulting in the formation of an epithelium fold, which immerses into the follicle lumen in the form of a papilla (Kachalka, 1986). Follicles of an irregular shape are also a characteristic feature of the thyroid gland of rats (Onwuaso et al., 2015).

The use of indices allows to characterize the functional features of the thyroid gland based on its morphological parameters (Davis \& Davis, 1954; Firdous $\&$ Karalathukaran, 2013). Thus, Brown index and folliclecolloid index characterize the activity of the gland based on its ability to accumulate colloid and synthesize iodinecontaining hormones. At the same time, the decrease of the first index and the increase of the second one, observed in PS rabbits, indicate an increase in the hormonal activity of the gland. The opposite option (increase of the first index and decrease of the second one), indicates a decrease in the hormonal activity of the gland passing on the background of high colloid secretion. To a different extent, this phenomenon is observed in NT and ST rabbits. Similar signs reveal themselves during the hypofunction of the gland, especially in the process of aging (Lee et al., 2016).

An increase in the amount of colloid caused by the decreased follicle activity leads to stretching and thinness of its walls. As a result, the shape of epithelial cells changes from cubic to flat, which corresponds to the data of Moghanlo and Mohammadpour, 2018. Also, the location of microvilli on the apical surface of the follicles is changing (Parchami \& Fatahian Dehkordi, 2012). Among the animals we studied, the sites with expanded follicles (Fig. 13) were detected in two NT rabbits (40\%) and six ST rabbits (33\%). In PS rabbits, such follicles were not detected. Their follicles were of a small size with a cylindrical epithelium. (Fig. 14).

Functional activity of the follicles can be evaluated based on the color of colloid inside them. According to Moghanlo and Mohammadpour, 2018, smaller, more active follicles contain a darker colloid, while larger and 
less active follicles contain a lighter colloid. The indicated pattern was also confirmed during our research.

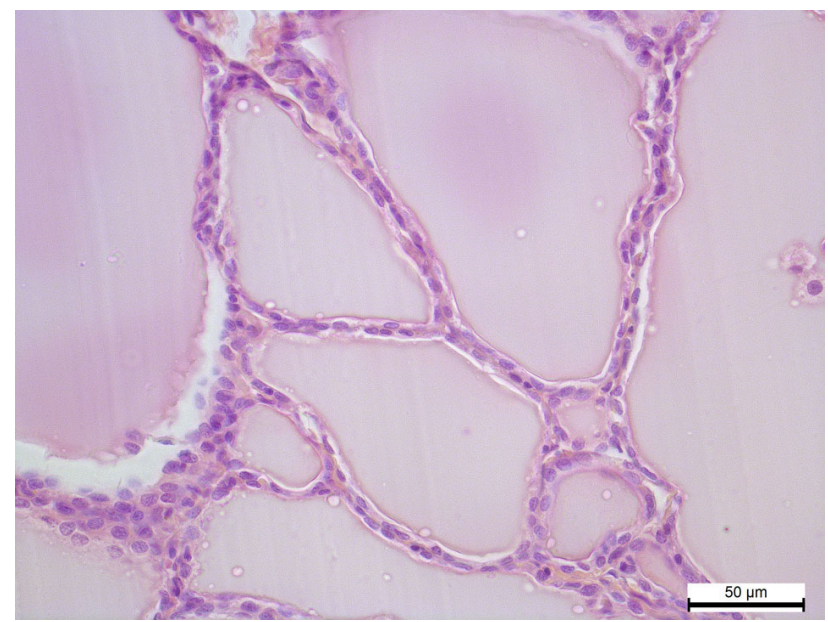

Fig 13. Follicles of the thyroid gland of ST rabbit. Hematoxylin and eosin 10x40

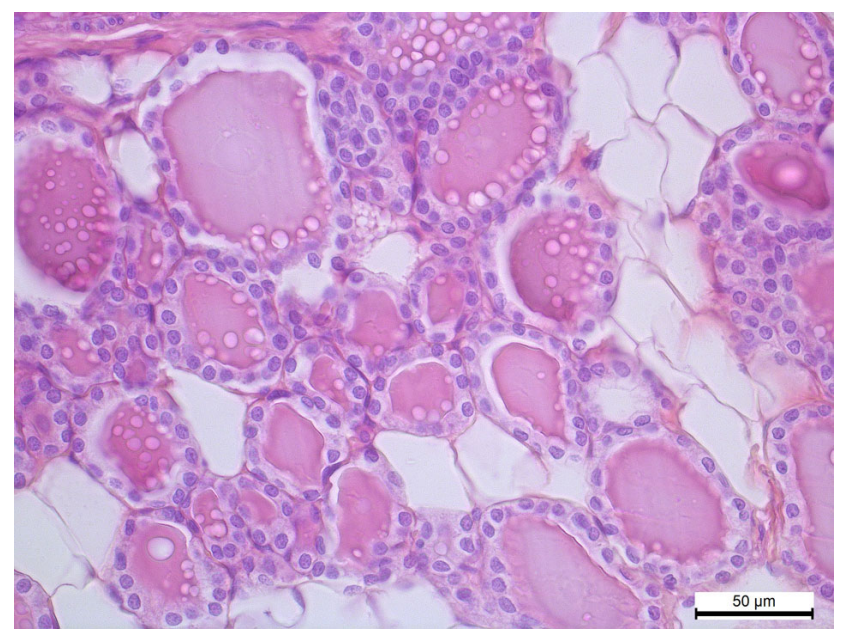

Fig 14. Follicles of the thyroid gland of PS rabbit. Hematoxylin and eosin 10x40

Morphofunctional parameters of thyroid gland of rabbits are characterized by different levels of correlation with the body weight of animals. To a certain extent, typological peculiarities of the autonomous tonus regulate this process. Similar correlations were found in birds, however, the features of autonomous regulation weren't taken into account (Firdous et al., 2012).

\section{Conclusion}

A correlation between the structure of the thyroid gland and the typological features of the autonomous tonus was established in the rabbits (Oryctolagus cuniculus (Linnaeus, 1758)). Considering all the morphometric indices and ratios between them, the PS rabbits are characterized by a functionally more active thyroid gland, which is also reflected in the higher values of body weight. Morphometric indices of thyroid gland of NT and ST rabbits indicate that the functional activity of the gland in these groups is approximately equal, but lower compared to the PS animals. A similar situation refers to the body weight. Considering seven out of fourteen indicators, PS rabbits outweigh other groups of animals.

\section{References}

Abdelatif, A. M., \& Saeed, I. H. (2009). Effect of altered thyroid status in the domestic rabbit (lepus cuniculus) on thermoregulation, heart rate and immune responses. Global Veterinaria, 3(6), 447-456. URL: https://www.semanticscholar.org/paper/Effect-ofaltered-thyroid-status-in-the-domestic-on-AbdelatifSaeed/8e32b0992bddf96e5fe668498347f87d31f172bf.

Alcaraz, M., Solano, F., Vicente, V., \& Canteras, M. (2003). Effect of radiation on thyroid peroxidase activity in rabbit. Radiobiologia: Revista electronica, 3(1), 59-62.

Al-Mustawfi, N. S., Al-Azawi, T. S., \& Mohammed, I. F. R. (2011). Effect of laser treatment on thyroid gland hormones in female rabbits. Iraqi Journal of Veterinary Sciences, 25(2), 61-64. doi: 10.33899/ijvs.2011.5644.

Baevskij, R. M., Kirilov, O. I., \& Kleczkin, S. Z. (1984). Matematicheskij analiz serdechnogo ritma pri stresse [Mathematical analysis of heart rate under stress]. Nauka, Moscow (in Russian).

Balasundaratn, K., \& Mookkappan, M. (2000). Histomorphology of the thyroid gland in the domestic fowl (Gallus domesticus). Journal of Veterinary and Animal Sciences, 31, 28-31.

Bessalova, E. Y. (2012). Stroenie shhitovidnoj zhelezy belykh krys pri vvedenii ksenogennoj spinnomozgovoj zhidkosti posle nastupleniya polovogo sozrevaniya [The structure of the thyroid gland of white rats with the introduction of xenogeneic cerebrospinal fluid after the onset of puberty]. Tavricheskij mediko-biologicheskij vestnik, 4(60), 68-69 (in Russian).

Borges, M. F., Modolo, I. M. B. B., Modolo, R. G. P., Silva, L. C., Mayumi, S. L., Tiveron, R. C., Scandiuzzi, D., \& Lima, M. A. (2014). Hyperthyroidism due to papillary thyroid carcinoma associated with ductal breast carcinoma. Case Reports in Clinical Medicine, 3(8), 479-486. doi: $10.4236 / \mathrm{crcm} .2014 .38105$.

Coll, S. A. (2014). Anatomical and histological study of thyroid gland in female local donkeys (Eqws africanus asinus) at Basrah city. Al-Qadisiyah Journal of Veterinary Medicine Sciences, 13(1), 85-87. doi: 10.29079/vol13iss1 art283.

Davis, J., \& Davis, B. S. (1954). The annual gonad and thyroid cycles of the english sparrow in southern california. The Condor, 6, 328-345. doi: $10.2307 / 1365019$.

El-Desouki, N. I., Afifi, D. F., El-Refaiy, A. I., \& Talaat, H. (2014). Age-related changes in histological and cytoskeletal intermediate filaments of rabbits thyroid glands and the prophylactic role of vitamin $E$. Global Veterinaria, 13(4), 511-519. doi: 10.5829/idosi.gv.2014.13.04.8625. 
Enemali, F. U., Hambolu, J. O., Alawa, J. N., \& Anosike, I. V. (2016). Gross Anatomical, Histological and Histochemical Studies of Thyroid Glands of African Giant Rat (Cricetomys gambianusWaterhouse, 1840). IOSR Journal of Pharmacy and Biological Sciences, 11(4), 40-43. doi: 10.9790/3008-1104024043.

Falin, L. I. (1961). Al'degid-fuksin i ego primenenie v gistohimii [Aldehyde-fuchsine and its use in histochemistry]. Arkhiv anatomii, gistologii i embriologii, 5, 85-88 (in Russian).

Fernandez-Santos, J. M., Morillo-Bernal, J., GarciaMarin, R., Utrilla, J. C., \& Martin-Lacave, I. (2012). Paracrine regulation of thyroid-hormone synthesis by c cells. Thyroid hormone. IntechOpen. doi: $10.5772 / 46178$.

Firdous, A. D., Lucy, K. M., \& Chungath, J. J. (2012). Comparison of thyroid gland parameters with body weight and age in kuttanad ducks during postnatal period. Journal of Veterinary Medicine and Animal Sciences, 43, 71-74. URL: https://journals.cvaslibrary. com/1_43_17.pdf.

Firdous, D., \& Karalathukaran, L. (2013). Epithelial diversification of thyroid gland in kuttanad duck (anas platyrhynchos domesticus) - a postnatal study. British Journal of Poultry Sciences, 2(1), 07-10. doi: 10.5829/idosi.bjps.2013.2.1.73154.

Forhead, A. J., \& Fowden, A. L. (2014). Thyroid hormones in fetal growth and prepartum maturation. Journal of Endocrinology, 221(3), 87-103. doi: 10.1530/JOE-14-0025.

Gachkar, S., Nock, S., Geissler, C., Oelkrug, R., Johann, K., Resch, J., Rahman, A., Arner, A., Kirchner, H., \& Mittag, J. (2019). Aortic effects of thyroid hormone in male mice. Journal of Molecular Endocrinology, 62(3), 91-99. doi: 10.1530/JME-18-0217.

Gao, Y., Lee, W. M., \& Cheng, C. Y. (2014). Thyroid hormone function in the rat testis. Frontiers in Endocrinology, 5, 188. doi: 10.3389/fendo.2014.00188.

Gibbons, P. M., Garner, M. M., \& Kiupel, M. (2012). Morphological and immunohistochemical characterization of spontaneous thyroid gland neoplasms in guinea pigs (Cavia porcellus). Veterinary Pathology, 50(2), 334-342. doi: 10.1177/0300985812447828.

Hmelnitskiy, O. K. (1998). Schitovidnaya zheleza kak ob'ekt morfometricheskogo issledovaniya [Thyroid gland as an object of morphometric research]. Arhiv patologii, 60(4), 47-49 (in Russian).

Igbokwe, C. O. (2010). Gross and microscopic anatomy of thyroid gland of the wild African grasscutter (Thryonomys swinderianus, Temminck) in Southeast Nigeria. European Journal of Anatomy, 14(1), 5-10. URL: http://eurjanat.com/web/paper.php?id=100002ci.

Johansson, E., Andersson, L., Örnros, J., Carlsson, T., Ingeson-Carlsson, C., Liang, S., Dahlberg, J., Jansson, S., Parrillo, L., Zoppoli, P., Barila, G. O., Altschuler, D. L., Padula, D., Lickert, H., Fagman, H., \& Nilsson, M. (2015). Revising the embryonic origin of thyroid C cells in mice and humans. Development, 142(20), 3519-3528. doi: 10.1242/dev.126581.

Jost, A. (1954). Hormonal factors in the development of the fetus. Cold Spring Harbor Symposia on
Quantitative Biology, 19, 167-181. doi: 10.1101/SQB.1954.019.01.023.

Kachalka, O. V. (1986). Prostranstvennaya organizacziya follikulov shhitovidnoj zhelezy u novorozhdyennykh detej [Spatial organization of thyroid follicles in newborns]. Arkhiv anatomii, gistologii i embriologii, 90(5), 63-68 (in Russian).

Krassas, G. E., Poppe, K., \& Glinoer, D. (2010). Thyroid function and human reproductive health. Endocrine Reviews, 31(5), 702-755. doi: 10.1210/er.2009-0041.

Lee, J., Yi, S., Kang, Y. E., Kim, H.-W., Joung, K. H., Sul, H. J., Kim, K. S., \& Shong, M. (2016). Morphological and functional changes in the thyroid follicles of the aged murine and humans. Journal of Pathology and Translational Medicine, 50(6), 426435. doi: 10.4132/jptm.2016.07.19.

Moghanlo, M. D., \& Mohammadpour, A. A. (2019). Anatomy and histomorphology of thyroid, parathyroid and ultimobranchial glands in Guinea fowl (Numida meleagris). Comparative Clinical Pathology, 28(1), 225-231. doi: 10.1007/s00580-018-2819-x.

Mulisch, M., \& Welsch, U. (2010). Mikroskopische technik. Spektrum Akademischer.

Mullur, R., Liu, Y. Y., \& Brent, G. A. (2014). Thyroid hormone regulation of metabolism. Physiological Reviews, 94(2), 355-382. doi: 10.1152/ physrev.00030.2013.

Onwuaso, I. C., Nwagbo, E. D., \& Umar, M. B. (2015). Ultrastructure of the thyroid gland in adult West African dwarf goat (Capra hircus). International Journal of Morphology, 33(2), 532-537. doi: $10.4067 / \mathrm{S} 0717-95022015000200020$.

Ortiga-Carvalho, T. M., Chiamolera, M. I., Pazos-Moura, C. C., \& Wondisford, F. E. (2016). Hypothalamuspituitary-thyroid axis. Comprehensive Physiology, 6(3), 1387-1428. doi: 10.1002/cphy.c150027.

Parchami, A., \& Fatahian Dehkordi, R. F. (2012). Histological structure of the thyroid gland in duck: a light and electron microscopic study. World Applied Sciences Journal, 16(2), 198-201. doi: $10.5281 /$ zenodo. 1057217 .

Parchami, A., \& Fatahian Dehkordi, R. F. (2012). Sex differences in thyroid gland structure of rabbits. European Journal of Applied Sciences, 4(6), 245-248. doi: 10.5281 /zenodo.1054733.

Sokolowska, J., Berczynska, J., Poweska, A., Rygiel, D., Olbrych, K., \& Urbanska, K. (2018). Immunohistochemical characteristic of $\mathrm{C}$ cells in European bison thyroid gland. Folia Histochemica et Cytobiologica, 56(4), 222-230. doi: 10.5603/FHC.a2018.0024.

Sugiyama, S. (1954). Studies of the histogenesis of the thyroid gland of the guinea pig. I. The thyroid cells (follicle cells and parafollicular cells). The anatomical record, 120(2), 363-377. doi: 10.1002/ar.1091200202.

Sugiyama, S., \& Yagizawa, T. (1951). On the postnatal histogenesis of the thyroid gland of the rabbit. Okajimas Folia Anatomica Japonica, 23(2), 67-79. doi: 10.2535/ofaj1936.23.2 67.

Vojtkevich, A. A., \& Zenzerov, V. S. (1968). Submikroskopicheskiye osnovy sekretirovaniya shhitovidnoj zhelezy [Submicroscopic basis of thyroid 
secretion]. Arkhiv anatomii, gistologii i embriologii, 55(10), 21-29 (in Russian).

Yang, J., Yi, N., Zhang, J., He, W., He, D., Wu, W., Xu, S., Li, F., Fan, G., Zhu, X., Xue, Z., \& Zhou, W. (2018). Generation and characterization of a hypothyroidism rat model with truncated thyroid stimulating hormone receptor. Scientific Reports, 8, 4004. doi: 10.1038/s41598-018-22405-7.
Zakrevska, M. V., \& Tybinka, A. M. (2019). Peculiarities of microstructure of the suprarenal glands of rabbits with different types of autonomic tone. Regulatory Mechanisms in Biosystems, 10(4), 415-421. doi: 10.15421/021962.

Zhedenov, V. N. (1987). Anatomiya krolika [Rabbit anatomy]. Sovetskaya nauka, Moskva (in Russian). 